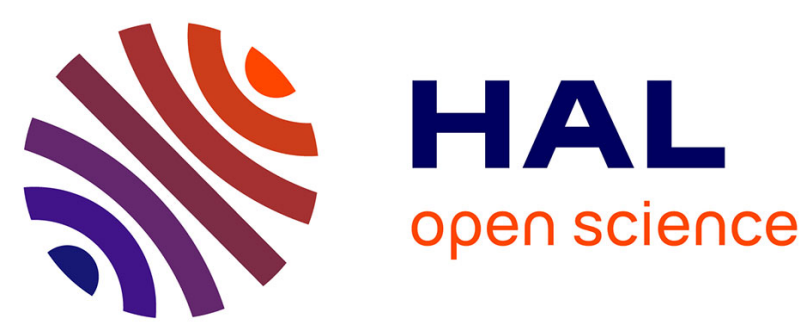

\title{
Assessment of the genotoxicity of quinolone and fluoroquinolones contaminated soil with the Vicia faba micronucleus test
}

Ahmed Khadra, Eric Pinelli, Marlène Z. Lacroix, Alain Bousquet-mélou, H Hamdi, Georges Merlina, Maritxu Guiresse, Mohamed Hatifi

\section{To cite this version:}

Ahmed Khadra, Eric Pinelli, Marlène Z. Lacroix, Alain Bousquet-mélou, H Hamdi, et al.. Assessment of the genotoxicity of quinolone and fluoroquinolones contaminated soil with the Vicia faba micronucleus test. Ecotoxicology and Environmental Safety, 2012, 76, pp.187-192. 10.1016/j.ecoenv.2011.10.012 . hal-01191262

\section{HAL Id: hal-01191262 \\ https://hal.science/hal-01191262}

Submitted on 1 Sep 2015

HAL is a multi-disciplinary open access archive for the deposit and dissemination of scientific research documents, whether they are published or not. The documents may come from teaching and research institutions in France or abroad, or from public or private research centers.
L'archive ouverte pluridisciplinaire HAL, est destinée au dépôt et à la diffusion de documents scientifiques de niveau recherche, publiés ou non, émanant des établissements d'enseignement et de recherche français ou étrangers, des laboratoires publics ou privés. 


\title{
Assessment of the genotoxicity of quinolone and fluoroquinolones contaminated soil with the Vicia faba micronucleus test
}

\author{
A. Khadra ${ }^{\text {a }}$ E. Pinelli ${ }^{\text {b,c,* }}$, M.Z. Lacroix ${ }^{\text {d,e }}$, A. Bousquet-Melou ${ }^{\text {d,e }}$, H. Hamdi $^{\text {a }}$,

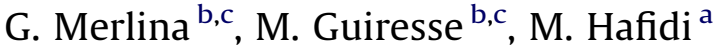 \\ a Laboratoire d'Ecologie et Environnement (Unité associée au CNRST, URAC 32, Unité associée au CNERS), Département de Biologie, \\ Faculté des Sciences Semlalia, Université Cadi Ayyad, BP 2390, Marrakech, Maroc \\ ${ }^{\mathrm{b}}$ Université de Toulouse, INPT, UPS, Laboratoire Ecologie Fonctionnelle et Environnement (EcoLab), ENSAT, Avenue de l'Agrobiopole, \\ 31326 Castanet Tolosan Cedex, France \\ ${ }^{c}$ CNRS, EcoLab, 31326 Castanet Tolosan Cedex, France \\ d INRA, UMR1331, Toxalim, F-31027 Toulouse, France \\ e Université de Toulouse, INPT, ENVT, EIP, UPS, F-31076 Toulouse, France
}

\section{A R T I C L E I N F O}

\section{Article history:}

Received 5 May 2011

Received in revised form

7 October 2011

Accepted 8 October 2011

Available online 1 November 2011

Keywords:

Antibiotics

Nalidixic acid

Ciprofloxacin

Enrofloxacin

Genotoxicity

Soil contamination

\begin{abstract}
A B S T R A C T
The genotoxicity of quinolone and fluroquinolones was assessed using the micronucleus (MN) test on Vicia faba roots by direct contact exposure to a solid matrix. Plants were exposed to quinolones (nalidixic acid) and fluoroquinolones (ciprofloxacin and enrofloxacin) alone or mixed with artificially contaminated soils. Four different concentrations of each of these antibiotics were tested $(0.01,0.1$, 1 and $10 \mathrm{mg} / \mathrm{Kg}$ ) for nalidixic acid and $(0.005,0.05,0.5$ and $5 \mathrm{mg} / \mathrm{Kg}$ ) for ciprofloxacin and enrofloxacin. These antibiotics were also used in mixture. Exposure of Vicia faba plants to each antibiotic at the highest two concentrations showed significant MN induction. The lowest two concentrations had no significant genotoxic effect. The mixture of the three compounds induced a significant MN induction whatever the mixture tested, from 0.02 to $20 \mathrm{mg} / \mathrm{Kg}$. The results indicated that a similar genotoxic effect was obtained with the mixture at $0.2 \mathrm{mg} / \mathrm{Kg}$ in comparison with each molecule alone at 5-10 mg/Kg. Data revealed a clear synergism of these molecules on Vicia faba genotoxicity.
\end{abstract}

(c) 2011 Elsevier Inc. All rights reserved.

\section{Introduction}

In recent years, public and scientific concern about the relevance of trace amounts of pharmaceuticals that occur in the environment has been continuously increasing (Pico and Andreu, 2007). Numerous pharmaceuticals have been detected in waste and natural water resources, sediments, soil and aquatic biota. While the pharmaceuticals are found at relatively low concentrations (Terns, 1998; Korpin et al., 2002), elevated concentrations of antibiotics (several $\mathrm{mg} / \mathrm{Kg}$ levels) have been reported in manure (Hamscher et al., 2002), sewage sludge and sewage-treated soil (Golet et al., 2003). Indeed after administration to humans, fifty to ninety percent of these pharmaceuticals or their primary metabolites are rapidly excreted into wastewater. In previous works (Golet et al., 2002, 2003), Fluoroquinolones (FQs) in raw sludge, wastewater effluents and river water samples were analyzed in Switzerland. They found out that a large proportion of FQs entering wastewater plants (89-92\% of the FQs mass flow) was

\footnotetext{
* Corresponding author at: Université de Toulouse, INPT, UPS, Laboratoire Ecologie Fonctionnelle et Environnement (EcoLab), ENSAT, Avenue de l'Agrobiopole, 31326 Castanet Tolosan Cedex, France. Fax: +33534323901.

E-mail address: pinelli@ensat.fr (E. Pinelli).
}

removed during the treatment processes. They also suggested that sewage sludge was the main source and reservoir of FQs residues (Golet et al., 2003). Sewage sludge is dispersed on the fields and the antibiotics may contaminate the soil and eventually the ground water (Hamscher et al., 2005).

Many drugs used in hospitals (antibiotics, cytostatic drugs) are designed to exhibit DNA damage toward bacteria or eukaryotic cells, raising concern about the human and ecological hazard of hospital wastewater (Giuliani et al., 1996). Ciprofloxacin was found in concentration ranging from 0.7 to $124.5 \mu \mathrm{g} / \mathrm{L}$ in hospital effluents and was assumed to be the main source of genotoxic effects measured with the UmuC test in these effluents (Hartmann et al., 1999). Fluoroquinolones have been reported to induce unscheduled DNA synthesis, DNA strand breakage, chromosome damage and micronuclei formation (Mc Queen et al., 1991; Holden et al., 1989; Bredberg et al., 1991; Ciaravinco et al., 1993; Curry et al., 1996; Gibson et al., 1998). In addition, FQs exert other toxic and genotoxic effects on animal and human cells. For example, exposure of Chinese hamster ovary cells or Syrian hamster embryo cells to nalidixic acid (NA) and ciprofloxacin (CIP) induced cytotoxic effects and micronucleus induction (Gibson et al., 1998). In vitro studies with human lymphocytes exposed to enrofloxacin (ENR) and ciprofloxacin revealed an 
<smiles>CCn1cc(C(=O)O)c(=O)c2ccc(C)nc21</smiles>

(MW: 232)<smiles>CC(C)(C1CC1n1cc(C(=O)O)c(=O)c2cc(F)c(N3CCNCC3)nc21)C(F)(F)F</smiles>

(MW: 331)

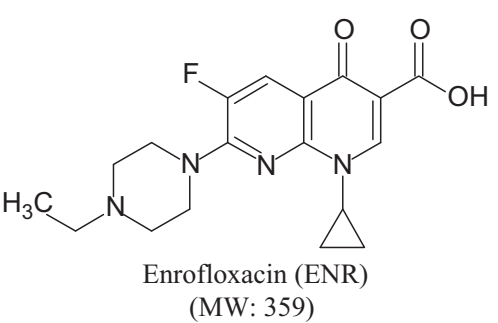

(MW: 359)

Fig. 1. Chemical structures and molecular weights of the antibiotics studied.

increase in the chromosomal aberrations, detected as chromatid and chromosome breaks and gaps (Gorla et al., 1999). FQs have been reported to cause neonatal alterations in articulation cartilages, bone growth and tendons, both in humans and animals (Patterson, 1991; Gough et al., 1992; Hildebrand et al., 1993; Forster et al., 1996; Simonin et al., 1999; Stahlmann, 2003; Lemus et al., 2009).

The Vicia faba micronucleus test has been shown to be sensitive in evaluating chromosomal aberrations and assessing genotoxicity from both organic and inorganic soil contaminants (Cotelle et al., 1999), sediment (Chen and White, 2004), organic material such as sewage sludge or composts (De Simone et al., 2000) and water (Miao et al., 1999; Monarca et al., 2004). No study has been conducted to test the genotoxic potential of quinolones and fluoroquinolones on Vicia faba plant roots. Because these molecules are significantly present in septic tank effluents pumped (STEP) wastewater and sludge, and because some countries use these products in plant cultivation, these antibiotics and more particularly quinolones and fluoroquinolones became a real environmental concern. In this work, the genotoxicity of quinolones (nalidixic acid) and fluoroquinolones (ciprofloxacin and enrofloxacin) (Fig. 1), alone or in mixture, were evaluated using the Vicia faba micronucleus test by direct contact with artificially contaminated soils.

\section{Materials and methods}

\subsection{Chemicals and reagents}

Ciprofloxacin (CIP), enrofloxacin (ENR), nalidixic acid (NA) and maleic hydrazide (MH) were purchased from Sigma-Aldrich. The purity of the chemicals used in this study was $>95 \%$ for all of the antibiotics. All the other chemicals used were of analytical grade. Stock solutions of ciprofloxacin, enrofloxacin, nalidixic acid and mixture were prepared in deionised water.

\subsection{Antibiotic analysis}

Antibiotic concentrations were checked by LC/UV/MS/MS. Chromatographic analyses were performed on a Thermofinnigan Surveyor ${ }^{\mathbb{R}}$ HPLC system with diode array detector (DAD) and a LCQ Deca XP Max ${ }^{\mathrm{B}}$ ion trap mass spectrometer (Thermo Electron Corporation, Waltham, Mass, USA). Separation was carried out with a Luna C18 column $(100 \times 2.0 \mathrm{~mm} ; 3 \mu \mathrm{m}$, Phenomenex, Torrance, CA, USA $)$ at $40{ }^{\circ} \mathrm{C}$. A gradient elution was used at a flow rate of $200 \mu \mathrm{L} / \mathrm{min}$ with a mobile phase of acetonitrile $0.1 \%$ formic acid (A) and water $0.1 \%$ formic acid (B) in the following conditions: $0-1 \mathrm{~min}, 90 \% \mathrm{~A} ; 1-8 \mathrm{~min}, 40 \% \mathrm{~A} ; 8-10 \mathrm{~min}, 40 \% \mathrm{~A}$; 10-11 $\mathrm{min}, 90 \% \mathrm{~A}$ and $11-15 \mathrm{~min}, 90 \% \mathrm{~A}$. The DAD wavelengths were set at $254 \mathrm{~nm}$ and $295 \mathrm{~nm}$ and molecules were ionized with an electrospray ionization source in positive mode (ESI+). The spray needle was set at a potential of $5 \mathrm{kV}$. Capillary voltage and temperature were $10 \mathrm{~V}$ and $350{ }^{\circ} \mathrm{C}$, respectively. Sheath gas and auxiliary gas flow rate of nitrogen were set at 45 and 10 (arbitrary units), respectively. Helium was used in the trap as damping and collision gas. Collision energies $\left(E_{\text {coll }}\right)$ were optimized for each antibiotic (Table 2A). CIP, ENR and NA were assayed by HPLC with UV detection and mass spectrometry (MS) using the selection reaction monitoring mode (SRM). The detection parameters are reported in Table 2A.

In mass spectrometry, the parent ion of CIP, ENR and NA was the protonated molecular ions $[\mathrm{M}+\mathrm{H}]^{+}$and their fragment ions were $[\mathrm{M}+\mathrm{H}-18]^{+}$and/or
Table 1

Key properties of the LUFA standard soil.

\begin{tabular}{ll}
\hline Organic carbon (\%) & 2.33 \\
pH (soil:water, 1:2.5) & 5.7 \\
Cation exchange capacity (mval/100 g) & 11 \\
Particle size (mm) distribution according to USDA (\%) & \\
$<0.002$ & 7.9 \\
$0.002-0.05$ & 14.2 \\
$0.05-2.0$ & 77.9 \\
Soil type & Loamy sand \\
\hline
\end{tabular}

Table 2A

Chromatographic, UV detection and MRM parameters used for quinolone quantification in preparation solution and in mixture.

\begin{tabular}{|c|c|c|c|c|c|}
\hline & \multicolumn{2}{|l|}{ UV detection } & \multicolumn{3}{|l|}{ MS detection } \\
\hline & $\begin{array}{l}\operatorname{tr} \pm \mathrm{SD} \\
(n=6)(\min )\end{array}$ & $\begin{array}{l}\lambda_{\mathrm{abs}} \\
(\mathrm{nm})\end{array}$ & $\begin{array}{l}\operatorname{tr} \pm S D \\
(n=6)(\min )\end{array}$ & $\begin{array}{l}\text { MRM } \\
\text { transitions }\end{array}$ & Ecoll (\%) \\
\hline Nalidixic acid & $9.63 \pm 0.008$ & 254 & $9.87 \pm 0.014$ & $\begin{array}{l}233<233 \\
233<215\end{array}$ & 38 \\
\hline Enrofloxacin & $4.89 \pm 0.030$ & 295 & $5.12 \pm 0.034$ & $\begin{array}{l}360<342 \\
360<316\end{array}$ & 36 \\
\hline Ciprofloxacin & $3.37 \pm 0.031$ & 295 & $3.60 \pm 0.029$ & $\begin{array}{l}332<314 \\
332<288\end{array}$ & 38 \\
\hline
\end{tabular}

$[\mathrm{M}+\mathrm{H}-44]^{+}$corresponding to the loss of $\mathrm{H}_{2} \mathrm{O}$ and $\mathrm{CO}_{2}$, respectively, in accordance with the fragmentations reported in the literature (Yang et al., 2008). Antibiotic preparation solution and mixture were directly quantified before soil contamination with either UV detection for the higher nominal concentrations of 1 or 2 and 10 or $20 \mathrm{mg} / \mathrm{L}$ (calibration range: $0.5-50 \mathrm{mg} / \mathrm{L}$ ) or mass spectrometry for the lower concentrations of 0.1 or 0.2 and 1 or $2 \mathrm{mg} / \mathrm{L}$ (calibration range: $0.1-10 \mathrm{mg} / \mathrm{L}$ ).

\subsection{Vicia faba micronucleus test}

LUFA standard soil was used in all direct contact experiments (Song et al., 2007). Some key characteristics of the LUFA standard soil are presented in Table 1. The Vicia faba seeds were prepared according to Ma et al. (1995), El Hajjouji et al. (2007) and Marcato-Romain et al. (2009). Dry Vicia faba seeds were soaked for $24 \mathrm{~h}$ in deionised water, the seed coats were removed and the seeds left to germinate between two layers of moist cotton. After 5 day, the primary roots, about $2-3 \mathrm{~cm}$ in length, were selected for the MN assay and their tips were cut off to promote the growth of the secondary roots. For each experiment, five plants were used as five independent replicates per treatment.

After the germination period, the direct contact method developed by Marcato-Romain et al. (2009) was used by placing germinated roots in the LUFA standard soil for the assessment of the effect of the three antibiotics. Four different concentration levels of each of these molecules were tested $(0.01,0.1,1$ and $10 \mathrm{mg} / \mathrm{Kg})$ for NA and $(0.005,0.05,0.5$ and $5 \mathrm{mg} / \mathrm{Kg})$ for CIP and ENR. A two-fold higher concentration range was used for NA because its potency against susceptible bacteria is at least two-fold lower than that of CIP and ENR. For each concentration, five replicates were processed. These antibiotics were also applied in mixture. In these cases, the mixture $0.02 \mathrm{mg} / \mathrm{Kg}$ corresponds to the mixture of $\mathrm{NA}$ at $0.01 \mathrm{mg} / \mathrm{Kg}$, CIP and ENR at $0.005 \mathrm{mg} / \mathrm{Kg}$. The same mixtures were realized with final concentrations of $0.2,2$ and $20 \mathrm{mg} / \mathrm{Kg}$ of each of these compounds. 
The maximal concentration corresponded to the fluoroquinolones analyzed in the sewage sludge and sewage-treated soil (Golet et al., 2003). For each condition tested, moisture at 2/3 of water holding was maintained by introducing solutions prepared of antibiotics at the bottom of the pots to avoid possible anoxia. Positive controls were made of LUFA standard soil whose moisture was maintained using a solution of maleic hydrazide $\left(10^{-5} \mathrm{M}\right)$. LUFA standard soil wetted with distilled water was used as negative control. The total duration of the experimentation was 3 days.

In all experiments, at least five root tips were collected per plant that is to say at least 25 tips per treatment. Root tips were rinsed with distilled water, fixed in aceto-ethanol $(1: 3, \mathrm{v} / \mathrm{v})$ at $4{ }^{\circ} \mathrm{C}$ overnight, rinsed again with deionized water for $10 \mathrm{~min}$ and transferred to ethanol before storage. Then, root tips were hydrolyzed with $1 \mathrm{~N} \mathrm{HCl}$ for $6 \mathrm{~min}$ at $60{ }^{\circ} \mathrm{C}$ and squash preparations were stained with $1 \%$ aceto-orcein for $3 \mathrm{~min}$ at $60{ }^{\circ} \mathrm{C}$. Five slides were prepared for each of the five seeds (one slide per root tip) and at least 1500 cells were counted per seedling, i.e. MN frequency was obtained from at least six thousand cells per treatment. The interphase cells as defined by Ma et al. (1995) were scored for MN frequencies at $400 \times$ magnification. Mitotic index (MI) was expressed in \% while MN frequencies were expressed in per 1000 cells. In order to avoid underestimation of $\mathrm{MN}$ frequency due to impaired cell proliferation rate, the MN test was performed only in the roots tips with a mitotic index greater than $2 \%$ (Ma et al. 1995). Statistical analysis was performed on the data: the Mann-Whitney $U$-test was used to determine the significance level against the negative control in each experimental MN test series (Béraud et al., 2007).

\section{Results}

\subsection{Quinolone and fluoroquinolones analysis}

NA, ENR and CIP measured concentrations of preparation solutions and mixtures are reported in Table 2B. Results of the intermediate concentrations ( 1 or $2 \mathrm{mg} / \mathrm{L}$ ) assayed by both LC/UV and LC/MS showed a very high correspondence between the two methods (not shown). These results also showed good correspondence between nominal and measured concentrations.

\subsection{Genotoxicity evaluation of antibiotic}

The genotoxic activities of quinolones (NA) and fluoroquinolones (CIP and ENR) evaluated by the Vicia faba Micronucleus test are shown in Table 3. For all the antibiotics tested, the mitotic index was greater than $2 \%$, and not significantly different from the two controls. At the two lowest concentrations, the three antibiotics had no significant effect on MN frequency compared to the negative control. At the two highest concentrations MN frequencies increased dose dependency. The most marked effect was observed in Vicia faba roots exposed to the highest concentrations (5 or $10 \mathrm{mg} / \mathrm{Kg}$ ), reaching $30-49 \%$ of the effect obtained in the positive control (Table 3 ). The 10 -fold increase of concentrations (from 1 to $10 \mathrm{mg} / \mathrm{Kg}$ for NA and from 1 to $5 \mathrm{mg} / \mathrm{Kg}$ for CIP) was associated with a 2 fold increase of the number of micronucleus: from 6.5 to $12.8 \%$ and 6.2 to $11.9 \%$, respectively. In the same

Table 2B

Nominal concentrations of 10 and $20 \mathrm{mg} / \mathrm{L}$ : LC/UV assay. Nominal concentration of 1 and $2 \mathrm{mg} / \mathrm{L}$ : mean values of both LC/UV and LC/MS assays. Nominal concentration of 0.1 and $0.2 \mathrm{mg} / \mathrm{L}$ : LC/MS assay.

\begin{tabular}{|c|c|c|c|c|c|}
\hline \multicolumn{6}{|c|}{ Mean concentration $(\mathrm{mg} / \mathrm{L})$ and SD $(n=3)$} \\
\hline \multicolumn{2}{|c|}{ Nalidixic acid } & \multicolumn{2}{|c|}{ Enrofloxacin } & \multicolumn{2}{|c|}{ Ciprofloxacin } \\
\hline Nominal & $\begin{array}{l}\text { Measured } \\
\text { mean (SD) }\end{array}$ & Nominal & $\begin{array}{l}\text { Measured } \\
\text { mean (SD) }\end{array}$ & Nominal & $\begin{array}{l}\text { Measured } \\
\text { mean }(\mathrm{SD})\end{array}$ \\
\hline 0.2 & $0.208 \pm 0.001$ & 0.1 & $0.121 \pm 0.006$ & 0.1 & $0.106 \pm 0.007$ \\
\hline 2 & $2.09 \pm 0.078$ & 1 & $0.957 \pm 0.031$ & 1 & $0.945 \pm 0.107$ \\
\hline 20 & $22.8 \pm 0.208$ & 10 & $10.4 \pm 0.184$ & 10 & $11.4 \pm 0.311$ \\
\hline \multicolumn{6}{|l|}{ Mixture } \\
\hline 0.2 & $0.275 \pm 0.055$ & 0.1 & $0.118 \pm 0.001$ & 0.1 & $0.101 \pm 0.002$ \\
\hline 2 & $2.12 \pm 0.214$ & 1 & $1.1 \pm 0.124$ & 1 & $0.924 \pm 0.144$ \\
\hline
\end{tabular}

Table 3

Evaluation of genotoxic effect of quinolones using the micronucleus test. Vicia faba roots were exposed by direct contact to soil contaminated by antibiotics at four different concentrations.

\begin{tabular}{lccc}
\hline & \% Mitotic cells & \%o MN & \% Effect \\
\hline Negative control & $7.4 \pm 0.4$ & $1.6 \pm 1.21$ & 0 \\
Positive control (MH) & $5.9 \pm 0.9$ & $24.6 \pm 1.42^{* * *}$ & 100 \\
Nalidixic acid & & & \\
$0.01 \mathrm{mg} / \mathrm{Kg}$ & $7.1 \pm 0.6$ & $2.3 \pm 0.5$ & 3.04 \\
$0.1 \mathrm{mg} / \mathrm{Kg}$ & $7.6 \pm 0.8$ & $3.3 \pm 1.5$ & 7.39 \\
$1 \mathrm{mg} / \mathrm{Kg}$ & $7.2 \pm 1.1$ & $6.5 \pm 0.5^{* * *}$ & 21.3 \\
$10 \mathrm{mg} / \mathrm{Kg}$ & $7.5 \pm 1.2$ & $12.8 \pm 2.8^{* * *}$ & 48.7 \\
Ciprofloxacin & & & \\
$0.005 \mathrm{mg} / \mathrm{Kg}$ & $7.0 \pm 0.3$ & $1.6 \pm 1.1$ & 0.01 \\
$0.05 \mathrm{mg} / \mathrm{Kg}$ & $6.5 \pm 0.6$ & $2.1 \pm 0.8$ & 2.17 \\
$0.5 \mathrm{mg} / \mathrm{Kg}$ & $6.8 \pm 0.4$ & $6.2 \pm 0.6^{* * *}$ & 20.0 \\
$5 \mathrm{mg} / \mathrm{Kg}$ & $6.7 \pm 0.8$ & $11.9 \pm 1.2^{* * *}$ & 44.8 \\
Enrofloxacin & & & \\
$0.005 \mathrm{mg} / \mathrm{Kg}$ & $6.7 \pm 0.2$ & $1.2 \pm 0.9$ & 0.01 \\
$0.05 \mathrm{mg} / \mathrm{Kg}$ & $7.1 \pm 0.4$ & $2.3 \pm 0.5$ & 3.04 \\
$0.5 \mathrm{mg} / \mathrm{Kg}$ & $6.0 \pm 0.9$ & $5.2 \pm 0.4^{* * *}$ & 15.7 \\
$5 \mathrm{mg} / \mathrm{Kg}$ & $6.6 \pm 0.6$ & $8.5 \pm 1.3^{* * *}$ & 30.0 \\
\hline
\end{tabular}

Each value represents mean \pm SD of 5 independent experiments. * and ${ }^{* *}$ represent statistically significant value at $p<0.05$ and $p<0.01$, respectively.

\section{Table 4}

Mitotic index and MN frequency values in Vicia faba root exposed by direct contact to the mixture of the three antibiotics at different concentrations.

\begin{tabular}{lccc}
\hline Treatments & \% Mitotic cells & \% MN & \% Effect \\
\hline Negative control & $6.9 \pm 0.4$ & $2.0 \pm 1.25$ & 0 \\
Positive control (MH) & $6.4 \pm 0.5$ & $22 \pm 1.75^{* * *}$ & 100 \\
Mixtures & & & \\
Mixture 0.02 mg/Kg & $7.15 \pm 0.3$ & $6.7 \pm 0.76^{* * *}$ & 23.5 \\
Mixture $0.2 \mathrm{mg} / \mathrm{Kg}$ & $6.6 \pm 0.3$ & $11 \pm 0.48^{* *}$ & 45.0 \\
Mixture $2 \mathrm{mg} / \mathrm{Kg}$ & $6.0 \pm 0.5$ & $16 \pm 1.62^{* *}$ & 70.0 \\
Mixture $20 \mathrm{mg} / \mathrm{Kg}$ & $6.8 \pm 0.28$ & $20.4 \pm 1.85^{* *}$ & 92.0 \\
\hline
\end{tabular}

Each value represents mean \pm SD of 5 independent experiments. * and ${ }^{* *}$ represent statistically significant value at $p<0.05$ and $p<0.01$, respectively.

conditions, micronucleus induced by enrofloxacin increased by only $60 \%$ (5.2 to 8.5$)$.

\subsection{Genotoxicity evaluation of antibiotic mixtures}

The results of the genotoxicity assessment of quinolone mixtures are presented in Table 4 . For all the experiments, the \% of mitosis was always higher than $2 \%$ and not significantly different from the negative control. Results revealed a significant and concentration dependent MN induction whatever the mixture tested, from 0.02 to $20 \mathrm{mg} / \mathrm{Kg}$. In these experimental conditions, MN induction increased dose dependency. The maximal genotoxic effect obtained with the mixture at $20 \mathrm{mg} / \mathrm{Kg}$ represented $92 \%$ of the effect obtained with the positive control. Interestingly, the range of maximal effects obtained with each molecule alone at $5-10 \mathrm{mg} / \mathrm{Kg}(30-49 \%)$ was obtained with the mixture at $0.2 \mathrm{mg} / \mathrm{Kg}(45 \%)$.

\section{Discussion}

The compounds studied in this work were described to be "readily biodegradable", with a low biodegradation rate (Kümmerer et al., 2000). These physico-chemical properties coupled to these antibiotic effects explain their high concentrations in sewage sludge and sewage-treated soil (Golet et al., 
2003). In view of the genotoxic character of quinolones and fluoroquinolones, it was important to evaluate their effect in soil, by direct contact with whole plant roots. For this purpose, the Vicia faba micronucleus (MN) test has been used with a method developed by Marcato-Romain et al. (2009). The Vicia faba micronucleus test is a very sensitive and useful method that allows detection of both clastogenic and aneugenic effects (El Hajjouji et al., 2007). Micronuclei are the result of chromosome breaks or mitotic anomalies that require a passage through mitosis to be recognizable.

The substances investigated represent a clinically important type of antibiotic drugs that are structurally related to nalidixic acid. These compounds target the A subunit of DNA gyrase and are effective inhibitors of this enzyme (Curry et al., 1996). The most active compounds with the broad antibacterial spectrum are the C-6 fluorinated quinolones and 1-8-naphthyridines that have a cyclic amino group at position 7 (Radl, 1990) as ENR and its principal metabolite CIP (Gorla et al., 1999). However, quinolones have exhibited varying degrees of cross-reactivity with mammalian topoisomerase II, which is a gyrase-like enzyme, and certainly with other replication enzymes (Bredberg et al., 1991). These compounds stabilize DNA-gyrase complex and stimulate topoisomerase II cleavage of DNA (Robinson et al., 1991). Fluoroquinolones also showed cross reactivity with other enzymes involved in the process of DNA replication (Bredberg et al., 1991). In addition, these compounds induced a variety of genotoxic effect due to their ability to inhibit topoisomerase II activities, including induction of transient DNA strand breaks during replication, chromosome condensation and disjunction during meiosis (Ferguson and Baguley, 1994; Heisig, 2009). In plants, topoisomerase II exists, and exerts the same role in DNA replication and cell proliferation (Fukata et al., 1986; Reddy et al., 1999).

The results presented in Table 3 revealed the genotoxicity of these compounds on Vicia faba root tips. MN induction appears significant for concentrations of $1 \mathrm{mg} / \mathrm{Kg}$ of NA, and $0.5 \mathrm{mg} / \mathrm{Kg}$ of CIP or ENR. For a higher concentration of antibiotics, the number of MN increased about 5.5 to 7 fold with ciprofloxacin. Results obtained for NA are not in agreement with the negative in vitro MN results reported by Albertini et al. (1995) and Gibson et al. (1998) in hamster CHO-K cells exposed to this compound. In a review by Forte (1992), NA was reported to be negative in an in vitro chromosome aberration assay. In contrast, NA was reported to stimulate unscheduled DNA synthesis in rat splenic cells and thymic cells in culture, but not in primary rat hepatocyte. ENR and CIP have been described to induce chromosomal aberrations in cultures of human lymphocytes at concentrations varying between 5 and $50 \mathrm{mg} / \mathrm{L}$ for ENR and 5 and $25 \mathrm{mg} / \mathrm{L}$ for CIP (Gorla et al., 1999). A reduction in the mitotic index and fuzzy metaphases were observed at $50 \mathrm{mg} / \mathrm{L}$ of ciprofloxacin, indicating a cytotoxic effect of this compound. In previous studies, Albertini et al. (1995) and Curry et al. (1996) reported significant increases in both chromosome aberration and in $\mathrm{MN}$ induction in the same range of ciprofloxacin concentration $(0.3-1.8 \mathrm{mM})$ than those observed by Gibson et al. (1998) in CHO-K1 cells. These results indicated the higher genotoxicity of ENR and CIP in comparison with NA. This is in agreement with our experimental conditions where CIP appears to be the most genotoxic compound.

The results of the literature also showed the low sensitivity of the mammalian MN test in comparison to the SOS chromotest or the UmuC test, which revealed the positive effect of ciprofloxacin at $0.7 \mu \mathrm{g} / \mathrm{L}$ (Hartmann et al., 1999). Topoisomerases-II inhibitors like CIP and ofloxacin are very strong genotoxicants in Escherichia coli PQ 37 (SOS chromotest) and highly mutagenic in Salmonella typhimurium TA 102 (Ames test) in absence of exogenous metabolizing system (Mersch-Sundermann et al., 1994). DNA damaging effect could be observed in concentration of approximately
$0.2-0.4 \mu \mathrm{g} / \mathrm{L}$ for CIP. It is important to emphasize that all these compounds are designed to inhibit the development of microorganisms and the high sensitivity observed remains normal. For CIP, the concentrations were 1000 to 10,000 fold lower than those inducing chromosomic aberrations in human lymphocytes $(5-25 \mathrm{mg} / \mathrm{L})$ or in V79 Chinese hamster lung cells $(200 \mathrm{mg} / \mathrm{L})$. The significant induction of MN obtained in our experimental conditions with concentration of quinolones ranging between 0.5 and $1 \mathrm{mg} / \mathrm{Kg}$ corresponding to 1 and $2 \mathrm{mg} / \mathrm{L}$, respectively, revealed the high sensitivity of this test, which is 10 to 100 fold more sensitive than the mammalian cell assay. The higher sensitivity observed with the Vicia faba MN test compared to the mammalian cell assay reveals firstly the rapid cross-reactivity of quinolones and more particularly fluoroquinolones for the enzymes of the plants replication system and secondly the role of these two antibiotics in the MN induction. These results also suggested (i) the mobility of these compounds from soil to roots to promote MN induction, even if CIP and ENR have been described to be absorbed into the solid phase (Pico and Andreu, 2007), and (ii) the exposure conditions with contaminated soil do not represent a limiting factor for the genotoxicity assessment.

The results in Table 4 highlight a strong synergism in MN induction when the three molecules were added altogether. In this condition, $\mathrm{MN}$ induction was significant at the lowest concentration tested. The number of MN induction observed at the nominal concentration of $0.02 \mathrm{mg} / \mathrm{Kg}$ was more than 3 fold higher than the negative control, whereas each compound tested separately presented negative effects at concentrations of $0.1 \mathrm{mg} / \mathrm{Kg}$ (NA) and $0.05 \mathrm{mg} / \mathrm{Kg}$ (ENR, CIP). It is noteworthy that the level of genotoxicity reached by the $0.02 \mathrm{mg} / \mathrm{Kg}$ mixture $(23.5 \%$ of the positive control) was achieved with each molecule alone at 0.5 or $1 \mathrm{mg} / \mathrm{Kg}$ (Tables 3 and 4). Such a result demonstrates a clear synergism of the mixture for genotoxic effects.

In these experimentations, no sign of toxicity appears on the root tips. In the same way, the number of mitoses remained constant whatever the concentration of quinolones (NA) and fluoroquinolones (ENR and CIP) tested. In the last decades, several studies suggested the concept of thresholds in genotoxicity (Lynch et al., 2003; Elhajouji et al., 2010). The MN test contributed to a large extent in understanding the dose-response relationship for aneugens and clastogens. For topoisomerase inhibitor-induced clastogenicity, this concept was also developed using MN induction in L5178Y mouse lymphoma cells as a genetic end-point (Lynch et al., 2003). On the basis of this test, Lynch et al. (2003) estimated the threshold for clastogenicity at $50 \mu \mathrm{g} / \mathrm{mL}$ for ciprofloxacin. This threshold depends on the time duration of exposure and on the cell type. In Vicia faba root tips, the significant induction of MN appeared at the lower concentration when the compounds were used simultaneously. These results suggest that if a threshold exists for each molecule, the presence of the other ones, which are known to inhibit the topoisomerase II, could act synergistically to promote $\mathrm{MN}$ induction: $0.5 / 1 \mathrm{mg} / \mathrm{Kg}$ for the molecules alone vs. $0.005 / 0.01 \mathrm{mg} / \mathrm{Kg}$ for the mixture (Tables 3 and 4). Two hypotheses could be proposed: (i) the mixture of the three molecules reduced the threshold values of the other ones on the topoisomerase II inhibition; (ii) the combination of the three molecules induced other phenomena, not directly related to topoisomerase II inhibition. It is today difficult to clearly explain this synergism, but many of these compounds exert various effects as mentioned above, that can interact at different levels in the replication system. Fluoroquinolones have been described to induce oxidative stress in bacteria (Becerra and Albesa, 2002) and in eukaryote cell lines (Pouzaud et al., 2004). The oxidative stress was described to play an important role in DNA-damage induction (Halliwel, 1990). So, the combination of different adverse effects such as inhibition of topoisomerase II activities 
and oxidative stress, which also leads to DNA break-down, could promote synergistic effect on MN induction.

So plant genotoxicity assays as the MN test on Vicia Faba roots are sensitive tests and provide reliable and quantitative mutagenic data, that allow to detect new mutagens or combination of mutagens (Kristen, 1997). They can be used to develop new techniques for advancing mutagenic knowledge and alternative first-tear assays in the evaluation of possible genetic damage of a contamination by environmental pollutants such as heavy metals, pesticides and more recently body or health-care products. They can also contribute to an in situ monitoring, which can be carried out on a global scale in media as aqueous biota or soils in relation to human activities (Grant, 1994). These tests represent a primary line bio-assay for a general human health genotoxic risk assessment.

\section{Conclusions}

In summary, this work demonstrated for the first time the genotoxicity of quinolones and more particularly fluoroquinolones in artificially contaminated soil. The results revealed the sensitivity of the Vicia faba MN test to evaluate genetic alterations due to these chemicals. This study also highlights the genotoxicity of the mixture of the three molecules tested at very low and realistic concentrations, which can be found in soil treated with contaminated wastewater or sludge. The synergism observed in the present study demonstrates the necessity to investigate the ecotoxicological effects of contaminants at low concentrations and in mixture.

\section{Acknowledgments}

The authors would like to thank the CNRS (France) and the CNRST (Marocco) for their financial support (Grant PRAD number 24497).

\section{References}

Albertini, S., Chetelat, A.A., Miller, B., Muster, W., Pujadas, E., Strobel, R., Gocke, E., 1995. Genotoxicity of 17-Gyrase and four mammalian topoisomerase II-poison in prokaryotic and eukaryotic test systems. Mutagenesis 10, 343-351.

Becerra, M.C., Albesa, I., 2002. Oxidative stress induced by ciprofloxacin in Staphylococcus aureus. Biochem. Biophys. Res. Commun. 297, 1003-1007.

Béraud, E., Cotelle, S., Leroy, P., Férard, J.F., 2007. Genotoxic effects and induction of phytochelatins in the presence of cadmium in Vicia faba roots. Mutat. Res. 633, 112-116.

Bredberg, A., Brant, M., Jaszyk, 1991. Ciprofloxacin-induced inhibition of topoisomerase II in human lymphoblastoid cells. Antimicrob. Agents Chemother. $35,448-450$.

Chen, G., White, P.A., 2004. The mutagenic hazards of aquatic sediments: a review. Mutat. Res. 567, 151-225.

Ciaravinco, V., Suto, M.J., Theiss, J.C., 1993. High capacity in vitro micronucleus assay for assessment of chromosome damage, results with quinolone naphthyridone antibacterials. Mutat. Res. 298, 227-236.

Cotelle, S., Masfaraud, J.F., Férard, J.F., 1999. Assessment of the genotoxicity of contaminated soil with the Allium/Vicia-micronucleus and the Tradescantiamicronucleus assays. Mutat. Res 426, 167-171

Curry, P.J., Kropko, M.L., Garvin, J.R., Fiedler, R.D., Theiss, J.C., 1996. In vitro induction of micronuclei and chromosomal aberrations by quinolones: possible mechanism. Mutat. Res. 352, 143-150.

De Simone, C., Tomati, U., Galli, E., Owczarek, M., De Marco, A., D’Ambrosio, C., Alianello, F., Cortellini, L., 2000. Evaluation of toxic and genotoxic activity of some composts from different origin. Fresenius Environ. Bull. 9, 683-690.

El Hajouji, H., Pinelli, E., Guiresse, M., Merlina, G., Revel, J.C., Hafidi, M., 2007. Assessment of the genotoxicity of olive mill waste water (OMWW) with the Vicia faba micronucleus test. Mutat. Res. 634, 25-31.

Elhajouji, A., Lukamowicz, M., Cammerer, Z., Kirsch-Volders, M., 2010. Potential thresholds for genotoxic effects by micronucleus scoring. Mutagenesis 26, 199-204.

Ferguson, L.R., Baguley, B., 1994. Topoisomerase II enzymes and mutagenicity. Environ. Mol. Mutagenesis 24, 245-261.
Forster, C., Kociok, K., Shakibaei, M., Merker, H.J., Stahlmann, R., 1996. Quinolone induced cartilage lesions are not reversible in rats. Arch. Toxicol. 70, 474-481.

Forte, F.L., 1992. Mutagenicity of quinolone antibacterials. Drug Saf. 7, 214-222.

Fukata, H., Ohgami, K., Fukasawa, H., 1986. Isolation and characterization of DNA topoisomerase II from cauliflower inflorescences. Plant Mol. Biol. 6, 137-144.

Gibson, D.P., Mo, X., Switzer, A.G., Murphy, V.A., Ardema, M.J., 1998. Comparative genotoxicity of quinolone and quinolonyl-lactam antibacterials in the in vitro micronucleus assay in Chinese hamster ovary cells. Environ. Mol. Mutagenesis $31,345-351$.

Giuliani, F., Koller, T., Würgler, F.E., Widmer, R.M., 1996. Detection of genotoxic activity in native hospital wastewater by the umuC test. Mutat. Res. 368, 49-57.

Golet, E.M., Alder, A.C., Giger, W., 2002. Environmental exposure and risk assessment of fluoroquinolone antibacterial agents in wastewater and river water of the Glatt Vally watershed, Switzerland. Environ. Sci. Technol. 36, 3645-3651

Golet, E.M., Xifra, I., Siegrift, H., Alder, A.C., Giger, W., 2003. Environmental exposure assessment of fluoroquinolone antibacterial agents from sewage to soil. Environ. Sci. Technol. 37, 3243-3249.

Gorla, N., Garcia Ovendo, H., Larripa, I., 1999. Chromosomal aberrations in human lymphocytes exposed in vitro to enrofloxacin and ciprofloxacin. Toxicol. Lett. 104, 43-48.

Gough, A.W., Kasali, O.B., Sigler, R.E., Baragi, V., 1992. Quinolone arthropathy-acute toxicity to immature articular cartilage. Toxicol. Pathol. 20, 436-450.

Grant, W.F., 1994. The present status of higher plant bioassay for the detection of environmental mutagens. Mutat. Res. 310, 175-185.

Halliwel, B., 1990. How to characterize a biological antioxidant. Free Radical Res. Commun. 9, 1-32.

Hamscher, G., Sczesny, S., Höper, H., Nau, H., 2002. Determination of persistent tetracycline residues in soil fertilized with liquid manure by high performance liquid chromatography with electrospray ionization tandem mass spectrometry. Anal. Chem. 74, 1509-1518.

Hamscher, G., Pawelzick, T.H., Höper, H., Nau, H., 2005. Different behaviour of tetracyclines and sulfonamides in sandy soils after repeated fertilization with liquid manure. Environ. Toxicol. Chem. 24, 861-868.

Hartmann, A., Golet, E.M., Gartiser, S., Alder, A.C., Koller, T., Widmer, R., 1999. Primary DNA damage but not mutagenicity correlates with ciprofloxacin concentrations in German hospital waste waters. Arch. Environ. Contam. Toxicol. 36, 115-119.

Heisig, P., 2009. Type II topoisomerases-inhibitors, repair mechanisms and mutations. Mutagenesis 24, 465-469.

Hildebrand, H., Kempka, G., Schluter, G., Schmidt, M., 1993. Chondrotoxicity of quinolones in vivo and in vitro. Arch. Toxicol. 67, 411-415.

Holden, H.E., Barett, J.F., Hutington, C.M., Muehebauer, P.A., Wahrenburg, M.G., 1989. Genetic profile of nalidixic acid and analog: a model for the mechanism of sister chromatid exchange induction. Environ. Mol. Mutagenesis 13, 238-252.

Korpin, D.W., Furlong, E.T., Meyer, M.T., Thurman, E.M., Zaugg, S.D., Barber, L.B., Buxton, H.T., 2002. Pharmaceuticals, hormones, and other organic wastewater contaminants in US streams, 1999-2000: a national reconnaissance. Environ. Sci. Technol. 35, 1202-1211.

Kristen, U., 1997. Use of higher plants as screens for toxicity assessment. Toxicol. in Vitro 11, 181-191.

Kümmerer, K., Al Ahmad, A., Mersh-Sundermann, V., 2000. Biodegradability of some antibiotics, elimination of the genotoxicity and affection of wastewater bacteria in a simple test. Chemosphere 40, 701-710.

Lemus, J.A., Blanco, G., Arroyo, B., Martinez, F., Grande, J., 2009. Fatal embryo chondral damage associated with fluoroquinolones in eggs of threatened avian scavengers. Environ. Pollut. 157, 2421-2427.

Lynch, A., Harvey, J., Aylott, M., Nicholas, E., Burman, M., Siddiqui, A., Walker, S., Rees, R., 2003. Investigations into the concept of a threshold for topoisomerase inhibito-induced clastogenicity. Mutagenesis 18, 345-353.

Ma, T.H., Xu, Z., Xu, C., McConnell, H., Rabago, E.V., Arreola, G.A., Zhang, H., 1995. The improved Allium/Vicia root tip assay for clastogenicity of environmental pollutants. Mutat. Res. 334, 185-195.

Marcato-Romain, C.E., Guiresse, M., Cecchi, M., Cotelle, S., Pinelli, E., 2009. New direct contact approach to evaluate soil genotoxicity using the Vicia faba micronucleus test. Chemosphere 77, 345-350.

Mc Queen, C.A., Way, B.M., Queeney, S.M., Schluter, G., Williams, G.M., 1991. Study of potential in vitro and in vivo genotoxicity in hepatocytes of quinolone antibiotics. Toxicol. Appl. Pharmacol. 111, 255-262.

Mersh-Sundermann, V., Schneider, U., Klopman, G., Rosenkranz, H.S., 1994. SOSinduction in E. coli and Salmonella mutagenicity: a comparison using 330 compounds. Mutagenesis 9, 205-224.

Miao, C.M., Fu, R., Yang, D., Zheng, L., 1999. Vicia root micronucleus assay on the clastogenicity of water samples from the Xiaoqing River in Shandong Province of the People's Republic of China. Mutat. Res. 426, 143-145.

Monarca, S., Zani, C., Richardson, S.D., Thruston, A.D., MorettiJr, A.D., Feretti, M.D., Villarini, M.A., 2004. New approach to evaluating the toxicity and genotoxicity of disinfected drinking water. Water Res. 38, 3809-3819.

Patterson, D.R., 1991. Quinolone toxicity: methods of assessment. Am. J. Med. 91, 35S-37S.

Pico, Y., Andreu, V., 2007. Fluoroquinolones in soil risk and challenges. Anal. Bioanal. Chem. 387, 1287-1299. 
Pouzaud, F., Bernard-Beaubois, K., Thevenin, M., Warnet, J.M., Hayem, G., Rat, P., 2004. In vitro discrimination of fluoroquinolones toxicity on tendon cells: involvement of oxidative stress. J. Pharmacol. Exp. Ther. 308, 394-402.

Radl, S., 1990. Structure activity relationships in DNA gyrase inhibitors. Pharmacol. Ther. 22, 1-17.

Reddy, M.K., Nair, S., Tewari, K.K., Mudgil, Y., Yadav, B.S., Sopory, S.K., 1999. Cloning and characterization of a cDNA encoding topoisomerase II in pea and analysis of its expression in relation to cell proliferation. Plant Mol. Biol. 41, 125-137.

Robinson, M.J., Martin, B.J., Gootz, T.D., McGuirk, P.R., Moynihan, M., Sutcliffe, J.A., Csheroff, N., 1991. Effects of quinolone derivatives on eukaryotic topoisomerase II: a novel mechanism for enhancement of enzyme mediated DNA cleavage. J. Biol. Chem. 266, 14585-14592.

Simonin, M.A.S., Pascale, G.P., Minn, A., Gillet, P., Netter, P., Terlain, B., 1999 Proteoglycan and collagen biochemical variations during fluoroquinolone induced chondrotoxicity in mice. Antimicrob. Agents Chemother. 43 2915-2921.

Song, Y.F., Gong, P., Wilke, B.M., Zhang, W., Song, X.Y., Sun, T.H., Ackland, M.L., 2007. Genotoxicity assessment of soils from wastewater irrigation areas and bioremediation sites using the Vicia faba root tip micronucleus assay. J. Environ. Monit. 9, 182-186.

Stahlmann, R., 2003. Children as a special population at risk-quinolones as an example for xenobiotics exhibiting skeletal toxicity. Arch. Toxicol. 77 7-11.

Terns, T., 1998. Occurrence of drugs in German sewage treatment plants and rivers. Water Res. 32, 3245-3260.

Yang, X., Hong, C., Ai, J., Hu, J., 2008. Trace analysis of quinolone and fluoroquinolone antibiotics from wastewaters by liquid chromatography-electrospray tandem mass spectrometry. J. Chromatogr. A 1214, 100-108. 